\title{
Инсценирующая диктатура: судебный процесс «Промпартии» 1930 г.
}

С.А. КРАСИЛЬНИКОВ, доктор исторических наук, Институт истории СО РАН, профессор, Новосибирский государственный университет, Новосибирск. E-mail: krass49@gmail.com

Аннотация. Поиск сталинским руководством в 1930 г. путей преодоления нараставших кризисных ситуаций внутри страны и за рубежом (рост социальной напряженности и протестных настроений в обществе по отношению к власти, межгосударственные торгово-экономические конфликты и т.д.) делал неизбежным уже апробированное обращение к технологиям социальной мобилизации в борьбе против «внутренних и внешних врагов» с использованием юстиции. Суд над мифической «Промпартией» стал первым в СССР полностью постановочным политическим процессом. В ходе его проведения властью впервые столь масштабно применялись в своем сочетании современные пропагандистские средства (киносъемка, радиотрансляция из зала суда, подневное освещение слушаний в газетах практически идентичное стенограмме) для воздействия на общественное сознание не только населения СССР, но и левых и рабочих движений зарубежных стран. Процесс «Промпартии» обладал также своей оборотной стороной, скрывавшей цели и намерения его организаторов, реконструировать которые позволяют служебные документы и материалы партийно-государственных и чекистских органов. В статье анализируется проблема возможностей и ограничений использования сталинским руководством данного судебного процесса в качестве средства управления поведением масс в раннесоветском обществе.

Ключевые слова: открытые судебные процессы; мифическая «Промпартия»; Сталин; Рамзин; Франция; «интервенционизм»

\section{«Если враг не сдается...». Большевистские судебные процессы как симбиоз идеологии и репрессий}

25 ноября 1930 г. в Москве начался продолжавшийся тринадцать дней и носивший ярко выраженный политико-пропагандистский характер открытый судебный процесс по т.н. делу «Промышленной партии» («Промпартии»). Восемь подсудимых обвинялись, а затем были приговорены по различным пунктам статьи 58-й УК РСФСР, в большинстве своем имевшим «расстрельную окраску». Для советской юстиции процесс имел беспрецедентный характер по степени публичности его проведения и освещения. Помимо публики в зале, насчитывавшей более 
полутора тысяч чел. и менявшейся по установленному порядку на каждом заседании, а также освещения каждого судебного дня в газете «Известия» с почти стенографической точностью, в зале суда работала группа кинодокументалистов, снимавших звуковой документальный фильм, велась радиотрансляция. Ничего подобного советская судебно-пропагандистская машина более не предпринимала. На процессе присутствовали журналисты крупнейших западных изданий, как левой, так и консервативной и антикоммунистической направленности, неподвластных советскому цензурному контролю.

Уже на стадии публикации в газете «Известия» «Обвинительного заключения» (11 ноября 1930 г.), а также в ходе процесса и по его завершении (приговор спецприсутствия Верховного Суда СССР был оглашен 7 декабря) сформировались две противоположные трактовки: официальная советская, доказывавшая правовую обоснованность обвинения и приговора, и «антисоветская», указывавшая на политическую ангажированность процесса, его постановочность, недоказанность вины подсудимых и т.д. Советская трактовка, практически исчезнувшая в постсоветский период из отечественной историографии и учебников, ныне заменена противоположной. Однако «победа» последней означала лишь механическую переполюсовку оценок без серьезного правового и историко-ретроспективного анализа того, что представлял собой его феномен. Отсюда вопросы: Зачем в 1930 г. власти потребовался новый «вредительский» процесс? Почему ему был придан формат «Промпартии»? Какими методами и средствами он обеспечивался? Были ли достигнуты поставленные его организаторами цели?

По своему драматическому воздействию на дальнейший ход отечественной истории 1930-й год ныне обоснованно помещается в ряд таких «переломных» дат, как 1917-й, 1937-й, 1941-й. Начавшись с январских партийных решений «о ликвидации кулачества как класса», санкционировавших форсированную принудительную коллективизацию и массовую высылку части крестьянских семей в спецпоселки, этот год завершался событием, напрямую затронувшим городские слои населения - судебным политическим процессом над группой научно-технической интеллигенции, обвинявшейся в создании и деятельности т.н. «Промышленной партии». По аналогии с тремя крупнейшими 
политическими процессами 1936-1938 гг. («Большими московскими процессами») над бывшими партийными и государственными лидерами страны, можно говорить о проведении на рубеже 1920-х - 1930-х гг. также трех «Больших вредительских процессов» - «Шахтинского» (1928), «Промпартии» (1930), «Меньшевистского» (1931). Эти показательные судебные процессы, имевшие одну общую основу - «вредительство», характеризовали начальную фазу (пролог) формирования сталинского режима, тогда как «троцкистско-бухаринские» процессы знаменовали завершение (утверждение) сталинизма.

Говоря о сходстве и различиях «вредительских» и «элитных» процессов в сталинскую эпоху, следует, прежде всего, выделить общие причины их организации. Они порождались самой природой тоталитарного режима, в основе которого - соединение мобилизационных и охранительных принципов с идеологическим их обеспечением. Данная триада составляла фундамент механизма власти в его взаимодействии с социальными слоями и группами во всех ключевых сферах (политика, экономика, культура, мировоззрение).

Показательные процессы, не имевшие ничего общего с правосудием, кроме судебной формы осуществления репрессий, выступали практически идеальным инструментом массовой соииальной мобилизации с целью консолидации и вовлечения широких слоев в реализацию грандиозных целей и программ «построения социализма» («борьба за») путем эксплуатации образа «врага» («борьба против» «спеца-вредителя», «троцкиста» и т.д.). Охранительная функция этих квазисудебных процессов реализовывалась двояко: в изоляции не столько потенциально опасных, сколько вымышленных противников режима (организованного антибольшевистского сопротивления после завершения Гражданской войны в стране не существовало) и в превентивных действиях (групповые и массовые аресты «врагов» формировали атмосферу страха и неуверенности в тех профессиональных группах, где репрессии осуществлялись). Идеолого-пропагандистское сопровождение показательных судебных процессов позволяло обеспечивать практически тотальное воздействие машины Агитпропа на массовое сознание населения страны. Помимо этого, предпринимались значительные усилия для распространения большевистской пропаганды о процессе в зарубежных странах. 
Показательные процессы на рубеже 1920-1930-х годов были актуальны в немалой степени еще и потому, что в советском обществе постоянно нарастала социальная напряженность. Они давали возможность канализировать массовое недовольство властью в сторону «врагов», поддерживать и культивировать идею социального реванша и возмездия, которая находила достаточно ожидаемый отклик в рабочей среде. Сформировавшаяся в 1928 г. в ходе подготовки и проведения Шахтинского судебного процесса платформа социальной ненависти к «спецам-вредителям» как носителям новой, пришедшей на смену «военной», формы контрреволюции («экономической»), имела все условия для того, чтобы быть воспроизведенной, что и произошло в конце 1930 г.

Что изменилось внутри страны и в мире за полтора года? Кризис в отношениях между большинством населения страны (не только крестьянством, но и рабочими) и институтами власти углублялся и приобретал новые формы. «Низовое» недовольство было опаснее открытого протестного поведения: волнения в городах и на производстве, связанные с перебоями в снабжении самыми необходимыми товарами и продовольствием, повышением интенсивности при ухудшении условий труда были чреваты своей непредсказуемостью. Кризис доверия к власти дополнялся и усиливался внутриэлитными столкновениями и противоречиями (разгром «правого уклона»). С конца 1929 г. наряду с социальной войной (против деревни) началась «кадровая революция» в собственных рядах («генеральная чистка» аппаратов управления и «чистка» рядов партии).

Внутриполитический кризис дополнялся начавшимся и принявшим затяжной характер мировым экономическим кризисом. В 1930 г. развернулись настоящие торгово-экономические войны, в том числе предпринятые группой западных стран против советского экспорта - от ограничений до частичного или полного запрета отдельных его видов. В логике мышления Сталина и его окружения такого рода действия означали близость и даже неизбежность вооруженной иностранной интервенции против СССР, которая не могла быть успешной без поддержки со стороны «внутренней контрреволюции». Главным резервом последней считалось «вредительство». В таком сочетании действия внутренних и внешних факторов и потребовалось организовать новый «Большой вредительский процесс» по «делу «Промышленной 
партии»», проходивший с 25 ноября по 7 декабря 1930 г. в Москве, в Колонном зале Дома Союзов.

\section{Целеполагание. Политический заказ. Почему «Промпартия»?}

В рамках современных концепций, объясняющих характер и природу показательных процессов раннесталинской эпохи, популярная модель «угрозы и вызова» в меньшей степени применима к объяснению данного феномена, нежели модель социальной мобилизации. Непосредственных внутренних и внешних угроз существованию большевистской власти, помимо тех, которые она порождала своими действиями, в стране на тот момент не было. Были и широко использовались технологии превентивного характера, позволявшие поддерживать высокий уровень социальной напряженности и конфликтности в обществе, с применением идеологических догм и пропагандистских стереотипов об «обострении классовой борьбы» и «СССР как осажденной крепости», вызванные необходимостью решать внутриполитические проблемы.

Однако только этими целями значимость самого инструмента судебного процесса не исчерпывалась. Планируя процесс, Сталин рассматривал необходимость придания ему международного характера. Возможность («подготовка») иностранной интервенции под эгидой Франции с вовлечением в конфликт стран т.н. санитарного кордона, граничивших с СССР, должна была, в логике марксистской доктрины, столкнуться с противодействием и массовыми протестами со стороны коммунистического и рабочего движения, левых кругов интеллигенции стран Европы. Внешнеполитическая составляющая замысла будущего процесса заключалась в развертывании мощной антивоенной кампании на Западе против «агрессивных планов» в отношении СССР, что позволяло выявить степень готовности политических и социальных сторонников и союзников СССР к протестным действиям в случае реальной войны, а также мобилизационный потенциал Коминтерна и его дочерних организаций.

Для сочетания такого рода составляющих (внутренняя «контрреволюция» на службе «внешнего интервенционизма») и с учетом внутренней ситуации в стране требовалась более «сильная» конструкция очередного процесса. Начавшееся с конца 1929 г. 
«социалистическое переустройство деревни» вызвало социальнополитическую дестабилизацию, отвлекло значительные средства и ресурсы государства. «Кулацкий» и «колхозный» вопросы оказались крайне острыми. В переписке Сталина с Молотовым летом - начале осени 1930 г. обсуждалась возможность организации открытого суда над Н.Д Кондратьевым, А.В. Чаяновым и другими арестованными экономистами-аграрниками в качестве лидеров мифической «Трудовой крестьянской партии» («ТКП»), на которую можно было возложить ответственность за массовое крестьянское сопротивление действиям власти в деревне. От этой идеи пришлось отказаться в немалой степени потому, что при всем усердии чекистов трудно было обосновать «связь» и тем более «руководство» интеллигентами-аграрниками повстанческой и стихийной протестной борьбой крестьянства в первой половине 1930 г. Кроме того, Кондратьев проявил неуступчивость, не пошел на признание связи с зарубежными кругами и планами «интервенции» [Письма..., 1995. С. 192-194, 211, 224].

Созданный чекистами партийный фантом в лице «ТКП» способствовал возникновению идеи о том, что внутренняя «контрреволюция» должна иметь статус партии - с платформой, идеологией, разветвленной сетью, финансами и пр. В 1930 г. в СССР можно было найти лишь бывших представителей политических партий эсеров, меньшевиков, анархистов. Их партийная деятельность была парализована еще в первой половине 1920-х гг. («непримиримые» сидели в тюрьмах и ссылках, а «разоружившиеся» работали в различных профессиональных сферах, не помышляя о какой-либо борьбе). Лидеры этих социалистических партий, находившиеся в эмиграции, категорически отрицали саму идею «интервенционизма». В сложившейся ситуации был выбран вполне прагматический путь: по аналогии с «ТКП» другой мифологической партией стала «Промышленная партия», к «созданию» которой чекисты приступили в сентябре 1930 г.

\section{«Есть такая партия!» Лидер - Л. К. Рамзин}

Социальной базой новой «партии» объявлялась т.н. буржуазная научно-техническая интеллигенция, которая уже с 1928 г. была обозначена как среда, рождавшая «вредительство». Ее «верхушка» сохранила свои корпоративные связи и профессиональные организации и в постреволюционный период, имела свое 
буржуазное прошлое, достаток. Крупные ученые и инженеры могли выезжать за рубеж в служебные командировки, для участия в международных конференциях. Это давало чекистам основания для «выявления» их «контактов» с эмигрантской экономической организацией - Торгово-промышленным союзом («Торгпром»), центр которой размещался в Париже. Все заработало, как только был произведен арест вернувшегося из зарубежной научной поездки известного ученого-теплотехника Леонида Константиновича Рамзина.

Почему Рамзин оказался в ранге руководителя мифической «Промпартии»? В «ТКП» аналогичная роль отводилась крупным и значимым в сфере аграрной экономики фигурам (Кондратьев, Чаянов). Рамзин, будучи известен в среде научно-технической интеллигенции (директор ведущего отраслевого Теплотехнического института, профессор МВТУ), все же не был столь авторитетной личностью. К тому же он имел неоднозначную репутацию человека авторитарного, амбициозного, карьериста, способного использовать и подчинять своим планам одних и дискредитировать других коллег, умевшего выстраивать связи с партийно-советскими функционерами. Частые поездки за рубеж на различные научные мероприятия и возможность общения с разными людьми позволяли чекистам обосновать «связи» Рамзина с эмигрантскими организациями (получение директив, обмен информацией), правительственными кругами Франции и в конце концов сделать его «руководителем партии». Рамзин был арестован 14 августа 1930 г. вскоре после возвращения из заграничной поездки. Шоковое состояние заключенного, еще недавно гулявшего по улицам европейских столиц, несомненно, способствовало склонению его к сотрудничеству со спецслужбами.

Почти месяц с момента ареста Рамзина на допросы не вызывали. Очевидно, он был подвергнут «внутрикамерной обработке» (использование агентов под видом заключенных для того, чтобы выведать необходимую для допросов информацию, а также склонить арестованных к даче «признательных показаний»). В учебном пособии для спецслужб описывается, видимо, именно этот случай («опыт внутрикамерной агентурной разработки объектов по следственному делу «Промпартии»»)), когда и как агент успешно справился со своей задачей. Оказавшись с одной камере с Р. («один из руководителей контрреволюционной организации 
«Промпартии»»), агент установил с ним контакт, вел продолжительные беседы, в ходе которых Р. якобы не просто раскрыл агенту всю информацию о «Промпартии», но и решил дать следствию развернутые показания о «ТКП», что послужило «началом раскрытия и ликвидации “ТКП”» [Следствие, 1941. С. 100-102].

Однако приведенный в пособии пример вызывает сомнения, так как по нему выходит, что Р. был реальным руководителем реально существовавшей «Промпартии», а также содействовал раскрытию «ТКП». Впрочем, Н.Д. Кондратьев был арестован 19 июня 1930 г. (Рамзин двумя месяцами позже), а вероятность постановочного процесса над «ТКП» обсуждалась значительно раньше, чем возникла идея «Промпартии», как третьего звена партийного альянса, наряду с «ТКП» и «меньшевиками». Сам Кондратьев летом 1930 г. подвергался активной внутрикамерной обработке, о чем он свидетельствует в своих заявлениях из Суздальского политизолятора в 1932 г. По другим источникам, накануне 1931 г. он говорил с сокамерниками о том, насколько опасно поддаваться подобной обработке, а оценивая поведение Рамзина, «бранил его “слабовольным болтуном”, перешедшим в своих показаниях все границы здравого смысла и здорового чувства самосохранения...» ${ }^{1}$.

17 сентября 1930 г. был зафиксирован протоколом первый допрос Рамзина, начинавшийся достаточно стереотипными для такого рода ситуаций словами: «Считаю необходимым заявить о том, что я решил прекратить всякую борьбу с советской властью и стать на путь прямого и искреннего разоружения и раскаяния». Далее он сделал несколько «ключевых» заявлений: о существовании с середины $1920-x$ гг. антисоветской организации «Союз инженерных организаций» (позже названной «Инженерным Центром»), осуществлявшей «вредительство» в основных сферах промышленности и транспорта. Назвал лиц, входивших в руководство, включая и себя (все они на тот момент были арестованы, а некоторые уже расстреляны). «Организация» якобы имела разветвленную сеть периферийных центров и филиалов; в 1927 г. была установлена связь «Инженерного центра» с «Крестьянской партией» (Чаянов); обсуждался вопрос о необходимости установления связей с эмигрантскими организациями.

${ }^{1}$ Центральный архив ФСБ РФ (ЦА ФСБ РФ). Ф. Р-42280. Т. 5. Л. 37. 
Краткие, двухстраничные показания Рамзина завершались также трафаретной фразой: «В последующем я дам исчерпывающие показания о всей известной мне деятельности нашего Центра и Крестьянской партии» ${ }^{2}$.

Далее, с 21 сентября он начал давать столь «исчерпывающие показания», что они занимали десятки страниц, исписанных убористым почерком. Рукопись от 21 сентября состояла из чернового текста на 34 страницах, написанных им собственноручно с рядом вставок на полях, включавшего в себя более 20 разделов - от истории создания «Центра», который уже именовался «Промышленной партией», и состава отраслевых и периферийных организаций до описания заседаний «руководства», начиная с 1927 г. «Дополнения» к предыдущему тексту на 10 страницах написаны 23 сентября, причем внизу каждой страницы он педантично ставил свою заверительную подпись. Выполненное Рамзиным в камере «домашнее задание», очевидно, способно поразить любого читателя своей детализацией: в рукописи упоминается более 80 фамилий (в большинстве с инициалами) лиц, которым приписывалась роль «руководителей» отраслевых центров с охватом всех отраслей промышленности и транспорта. В текстах приводятся конкретные цифры о состоянии базовых отраслей экономики. Даже с учетом тренированной памяти профессора технического вуза и ученого невозможно представить изложение такого объема информации, сидя в тюремной камере, «без подсказок». Особый интерес для политического руководства страны представляли несколько выделенных Рамзиным рубрик: «Ставка на интервенцию», «Вооруженное восстание», «Состав будущего правительства»; «Связь с белой эмиграцией и иностранными фирмами», «Заграничные директивы», «Отношение к правому уклону ВКП(б), «Связь с военной промышленностью», «Террористические группы» ${ }^{3}$.

Следующий обширный текст (24 страницы) Рамзин собственноручно «исполнял» в течение трех дней, поскольку сам их датировал периодом с 29 сентября по 1 октября (о связях с «правоуклонистами», о «террористической деятельности», «заграничных контактах» и «поддержке планов интервенции»). Черновики Рамзина были перепечатаны, и В.Р. Менжинский

${ }^{2}$ ЦА ФСБ РФ. Ф. Р-42280. Т. 2. Л. 1-1 об.

${ }_{3}^{3}$ Государственный архив Российской федерации. Ф. Р-9474. Оп. 7. Д. 405. Л. 2-30 об. 
имел все основания написать в докладной записке Сталину 2 октября 1930 г. следующее: «Очень прошу Вас прочесть показания известного <проф.> Рамзина. Во втором из них от 29/ IX-1/X с.г. Рамзин рассказывает, как промышленная партия (инж[енерный] вредительский центр) проводила свою линию по всем отраслям советской работы через Рыкова, Ломова и др. [...]. Новый момент в деле - террор: у Рамзина была террористическая группа из молодых инженеров. Здесь, как и в вопросе о военной организации, арестованные террористы начали признаваться» ${ }^{4}$. В ответном письме Сталин подчеркнул, что «самое интересное» в показаниях Рамзина - «это вопрос об интервенции вообще и особенно вопрос о сроке инт[ервен] ции». Если же показания Рамзина «получат подтверждение и конкретизацию в показаниях других обвиняемых (Громан, Ларичев, Кондратьев и Кㅇ и т.д.), то это будет серьезным успехом ОГПУ, так как полученный таким образом материал сделаем в той или иной форме достоянием секций К[оммунистического] И[нтернационала] и рабочих всех стран, поведем широчайшую кампанию против интервенционистов и добьемся того, что парализуем, подорвем попытки к интервенции на ближайшие 1-2 года, что для нас немаловажно» ${ }^{5}$.

Из сталинского письма Менжинскому следовали две директивы: центральное место в будущем судебном процессе должен занимать «интервенционизм», и в этом рамзинской «Промпартии» теперь отводилось приоритетное место. Чекистам следовало ускорить следственные действия в отношении «руководства» данной организации, максимально увязывая в один узел все три «контрреволюционные партии». Другая директива отражала своего рода сверхзадачу, в которой ведущая роль принадлежала советской пропаганде - придать будущему процессу международный резонанс, дабы «подорвать попытки к интервенции».

Для постановочного процесса такого рода требовался в качестве центральной фигуры незаурядный человек, амбициозный и одновременно гибкий, способный перешагнуть через границы морали. Примечательно, что уже по завершении процесса возглавлявший судебные заседания А.Я. Вышинский, выступая

\footnotetext{
${ }^{4}$ Архив Президента РФ. Ф. 3. ОП. 58. Д. 353. Л. 102-103.

${ }^{5}$ Коммунист. 1990. № 11. С. 99-100.
} 
9 декабря перед работниками аппарата Наркомпроса, назвал критерий, по которому Рамзин подходил для подобной роли: «Рамзин - человек в высшей степени крепкий. У нас было колебание: кто здесь главное действующее лицо - Федотов или Рамзин. Надо сказать, что Федотов - бывший член кадетской партии, который имеет все связи с деятелями контрреволюционной эмиграции. [...] В конце концов, у нас не было никакого сомнения, что первую скрипку играет Рамзин. Это человек с колоссальной волей, человек недюжинного ума, прекрасно владеющий тактикой маневрирования. Это передавалось и всем подсудимым, как по беспроволочному телеграфу - то, что скажет Рамзин, скажут и все остальные» [Судебный процесс... Кн. 2, 2017. С. 731].

Практически нет сомнений в том, что Рамзин, «изливая на бумагу» и легализуя чекистские заготовки, чем дальше, тем больше втягивался в предложенное ему мифотворчество, в котором «на кону» стояли реальные человеческие головы. Среди почти сотни человек, перечислением которых были насыщены первые рамзинские тексты, большинство уже сидели. Если предположить, что каким-то чудесным образом Рамзин мог знать об этом помимо «подсказок» чекистов, то здесь он еще не переступал грань между «допустимым» для арестованного соглашением со следователями и откровенным подыгрыванием следствию. Но затем он стал называть фамилии своих коллег по институту, другим организациям, еще находившихся на свободе, дав повод для новой волны арестов. Еще более отягчающим поведение Рамзина на следствии стал тот факт, что он (безусловно, по подсказке чекистов) заявил о наличии в структуре «Промпартии» направления террористической деятельности, по сути подводя перечисленных при этом людей под расстрельные приговоры (одним из троих впоследствии расстрелянных «руководителей террористических групп» стал двоюродный брат Рамзина, С.А. Предтеченский).

Арестованный по «рамзинскому перечню» в конце октября 1930 г. в Ленинграде инженер-технолог С.И. Краузе, которому Рамзин отвел роль одного из крупных вредителей в сфере военной промышленности, в заявлении на имя прокурора ОГПУ так охарактеризовал зловещую деятельность Рамзина: «Мое объяснение оговоров Рамзина. Рамзин, человек весьма талантливый, очевидно, попал в безвыходное положение, как контрреволюционер, и решил пропадать с большой помпой и шумом на весь культурный мир. 
Сколько правды, а сколько вымысла в его сочинении, “показаниях", я не берусь судить, как не берусь утверждать, что все это вымысел, ибо отвечать можно только за самого себя. Вероятно, Правда рамзински-талантливо смешана с Ложью, а цель смеси замешать как можно больше ценных и талантливых людей, снять их с работы и нанести этим огромный вред стране и ее текущим напряженным работам по индустриализации и подготовке кадров. В области теплотехники он достиг, кажется, этого полностью, ибо все видное и талантливое почти поголовно арестовано и обвиняется по самому ужасному преступлению - терроризму и взрыву заводов» ${ }^{6}$.

\section{Чекистская конкуренция:}

\section{как определялась “восьмерка» подсудимых}

Одним из очевидных различий между процессами Шахтинским и «Промпартии» является «многолюдность» скамьи подсудимых в 1928 г. (53 чел.) и «малолюдность» в 1930 г. (8 чел.). Данное обстоятельство следует отнести к урокам, извлеченным режимом из опыта проведения Шахтинского процесса: почти половина обвиняемых не признала (полностью или частично) себя виновными. Присутствие среди подсудимых трех немецких специалистов серьезно осложнило тогда германо-советские отношения. Наличие и квалифицированная работа значительной группы юристов-защитников (15 чел.) затрудняли Крыленко и Вышинскому ведение процесса в нужном для них русле. Соответственно, процесс «Промпартии» сопровождался более тщательным отбором подсудимых при резком сокращении их числа, наличием двух «вменяемых» защитников (опытных юристов М. А. Оцепа и И.Д. Брауде), знавших границы своих полномочий. Другим, неочевидным различием, является характерное для процесса «Промпартии» соперничество двух чекистских структур - Экономического управления (ЭКУ), курировавшего деятельность по «вскрытию вредительства», и Секретно-политического Отдела (СПО), занимавшегося разработкой более значительных, государственно-политических «дел».

Арестами и следственными действиями в отношении лиц, обвиненных во «вредительстве» во всех возможных отраслях

${ }^{6}$ ЦА ФСБ РФ. Ф. Р-42280. Т. 1. Л. 197. 
хозяйства, традиционно занимались сотрудники ЭКУ, поэтому первые аресты и допросы будущих фигурантов процесса «Промпартии» весной 1930 г. (проф. А.А. Федотова и других управленцев в сфере текстильной промышленности) проводились этим ведомством. Ситуация изменилась, когда в сентябре 1930 г. у руководства ОГПУ появилась схема «наличия» в стране контрреволюционных сил более высокого порядка - в виде «партий» («ТКП», «Промпартии», «меньшевистского бюро»). К разработке «партийных линий» были подключены структуры уже «политического сыска» во главе с Я.С. Аграновым. Именно им была передана следственная работа с основными «фигурантами» будущего процесса, включая Л. К. Рамзина. В итоге возникшей «конкуренции» каждая из групп следователей стремилась вывести своих подследственных на позиции ведущих деятелей мифической организации. Складывалась ситуация, при которой аресты и следствие начинали сотрудники ЭКУ, затем следствие «перехватывали» сотрудники СПО, а затем арестованных могли вновь возвращать в ведение ЭКУ, когда решался вопрос о послесудебном наказании.

\section{Как обеспечивался постановочный характер процесса}

Постановочный характер процесса «Промпартии» был обусловлен несколькими обстоятельствами, исключавшими пуск его на самотек. Прежде всего полным согласием подсудимых с предъявленными им обвинениями. Это достигалось путем целенаправленной и интенсивной работы следствия. Каждый из восьмерых четко осознавал отведенную ему на суде роль. Любой непредвзятый наблюдатель, оказавшийся «зрителем по пропуску» в Колонном зале, не мог не обратить внимание на то, что выступавшие подсудимые произносили речи или отвечали на вопросы почти не отрываясь от бумаг, лежавших перед ними. Вышинский, выступая перед сотрудниками Наркомпроса, так объяснял происходившее: «Перед нами сидели профессора, которые на меня и на других производили такое впечатление, что они, в сущности говоря, не дают объяснений, как подсудимые, а читают свои рефераты или доклады на каком то ученом собрании [...] У них были заметки, конспекты, куда они посматривали, и что давало впечатление, что они как будто читают свои объяснения. Конспекты эти они составляли 
в течение всего времени, какое они пробыли под стражей. Это было не так долго. Самый ранний арест был в апреле, самый поздний оказался в октябре, т.е. буквально за месяц до начала процесса. Это производило впечатление, что обвиняемые дают показания, читая заранее приготовленный материал и документы, что они читают, конечно, то, что им написало ГПУ, и вложило в их руки, а им остается только прочитать [...] Я смею удостоверить, что ни один из обвиняемых, несмотря на самую большую длительность речи, не читал того, что было написано, а обращался к написанному, как к документу помогающему развивать свои мысли, как это принято в нашем академическом кругу» [Судебный процесс... Кн. 2, 2017. С. 728].

Вышинский, естественно, говорил то, что и должен был говорить. Однако в действительности из восьми подсудимых четверо (А.А. Федотов, В.А. Ларичев, К. В. Ситнин и С. В. Куприянов) были арестованы во второй половине марта, «числились» за ЭКУ ОГПУ по линии «отраслевого вредительства» и вплоть до октября ни о какой «Промпартии» на их допросах не говорилось. Аресты «главарей» (И.А. Калинникова, Н. Ф. Чарновского, Л.К. Рамзина) прошли в июле - середине августа 1930 г., только В.И. Очкин, ученый секретарь Теплотехнического института, был арестован в октябре.

Безусловно, центральным объектом для чекистской работы был Рамзин. В следственном делопроизводстве зафиксировано 19 протоколов его допросов, среди которых большую часть составили его «собственноручные показания»- первый датирован 17 сентября, последний - 23 ноября, т.е. за два дня до начала судебного процесса. В дни 16 октября и 3 ноября он подвергался допросу дважды. В периоды с 10-го по 16-е и с 25-го по 31 октября допросы Рамзина проходили почти ежедневно. Главными темами были каналы связи с зарубежьем и направления, формы и масштабы «вредительства», планы «диверсий» на случай интервенции и, естественно, ключевой вопрос о «подготовке интервенции». Другой интенсивно допрашиваемой фигурой стал И.А. Калинников. Зафиксировано 16 протоколов его допросов, включая и «собственноручные показания». Пять протоколов были тиражированы. Как и в случае с Рамзиным, отмечены два пика интенсивности допросов - с 13-го по 18-е и с 27-го по 31 октября. Основными темами допросов были 
«вредительство в планировании развития промышленности» и «интервенционизм». Н.Ф. Чарновский допрашивался в период с 9-го октября по 3 ноября восемь раз, при этом четыре протокола тиражировались. С наибольшей интенсивностью допросы осуществлялись с 13-го по 18 октября, тематика-«вредительство в металлургии и машиностроении» в связи с «будущей интервенцией». В.А. Ларичев фигурировал в протоколах допросов также восемь раз с 6-го октября по 3 ноября, четыре протокола тиражировались, пик допросов приходился на период с 12-го по 18 октября. Тематика - «вредительство в планировании топливной промышленности» и «связь с заграницей». Допросы со стороны Секретно-оперативного управления ОГПУ курировал, нередко присутствуя на них, Я.С. Агранов. Основными следователями были Радзивиловский и Славатинский. Наконец, еще одна «ударная десятидневка» проходила с 13-го по 23 ноября, когда с подсудимыми проводились интенсивные передопросы, завершившись лишь за два дня до начала процесса. (Подсчеть сделаны нами на основе материалов следствия [Судебный процесс... Кн. 1, 2016. С. 28-30].)

Хронология допросов «главных» фигур «Промпартии» позволяет установить не только их динамику и «пиковые» значения в течение октября - ноября, но и то, над чем трудились чекистские следователи, стремясь увязать «экономическую контрреволюцию» с «интервенционизмом». Путем интенсивных допросов и передопросов, а также очных ставок арестованных между собой, выстраивался сценарий будущего процесса. Важно было устранить возникавшие на отдельных допросах нестыковки и противоречия. Рамзину, как центральной фигуре, на завершающей стадии следствия разрешалось передавать записки другим обвиняемым, дабы согласовывать показания уже в ходе судебных слушаний. Во время работы над следственными материалами, часть которых размножалась типографским способом для рассылки партийно-хозяйственному руководству, чекисты допускали перекраивание текстов допросов, убирая одни сюжетные линии и усиливая акценты в отношении других.

Весомым подтверждением постановочного характера процесса является четкая синхронность взаимодействий судебной машины с машиной Агитпропа. Содержание подневных заседаний в полном формате печаталось через день в газете «Известия», 
что было бы невозможным без высшей степени готовности того объема информации, которая озвучивалась в Колонном зале. По кадрам кинохроники видно, что каждый из подсудимых был «привязан» к тексту своего выступления, подготовленного заранее. Если после Шахтинского процесса в делопроизводстве Верховного Суда осталось 43 тома подневных стенограмм, так и не вышедших в свет, то стенограмма процесса «Промпартии», объединенная в один том, была отпечатана через три месяца по его завершении в варианте, практически повторявшем газетные подневные публикации «Известий». Сравнение судебной стенограммы с фрагментами выступлений подсудимых, зафиксированных кинохроникой, подтверждает их полную идентичность. То есть все источники говорят о полном перенесении информации судебных заседаний на «бумагу». Под жестким контролем проходила работа кинодокументалистов, выпустивших о процессе один из первых в стране звуковых фильмов («13 дней. Дело “Промпартии"», режиссер Я. Посельский). Давая заключение на смонтированный фильм, Вышинский отметил, что «монтаж сделан правильно и вполне выдержанно с идеологической и политической стороны» 7 . Через месяц после завершения процесса (5 января 1931 г.) фильм уже демонстрировался в кинотеатрах Москвы, а 13 января он был показан с титрами на английском языке в Нью-Йорке (во Франции и в Германии власти запретили показ фильма).

\section{«Издержки» и просчеты постановочного процесса}

К их числу следует отнести форсированные темпы проведения следствия, в ходе которого допускались грубые ошибки. Наибольший резонанс имел тот факт, что в показаниях Рамзина и др. фигурировали встречи за границей после 1927 г. с руководством эмигрантского «Торгпрома», в том числе с известным предпринимателем П.П. Рябушинским, хотя тот скончался еще в 1924 г. «Обстоятельства» встреч и переговоров Рамзина с представителями французских деятелей, включая военных, а также утверждение о том, что посольство Франции в СССР

\footnotetext{
${ }^{7}$ Российский государственный архив литературы и искусства. Ф. 2965. Оп.1. Д. 131. Л. 1.
} 
активно сотрудничало с лидерами «Промпартии», рассматривались в «особом порядке», в закрытом заседании суда перед завершением процесса. Но и там никаких конкретных доказательств представлено не было, чего требовала французская сторона по дипломатическим каналам. Французская сторона категорически отвергала любые обвинения в свой адрес, считая их необоснованными, а советская сторона, напротив, считала эти обвинения доказанными в суде. Полпред СССР во Франции В.С. Довгалевский 24 декабря 1930 г. передал министру иностранных дел Франции А. Бриану решение Верховного Суда СССР с сопроводительным письмом к нему. Днем позднее советский посол был вызван в МИД Франции, где ему предложили забрать документы, так как в них содержались «обвинения, не выдерживающие критики», а потому «неподлежащие принятию ни по форме, ни по содержанию» [Судебный процесс... Кн. 2, 2017. С. 257]. Советская сторона (М. М. Литвинов) вынуждена была констатировать, что «мы считаем протест заявленным, а французское правительство - не заявленным» [Судебный процесс... Кн. 2, 2017. С. 288]. Тем самым процесс «Промпартии» усугубил и без того имевшийся кризис в советско-французских взаимоотношениях, на преодоление которого ушел весь последующий 1931-й год. В итоге ставка советского руководства на «разоблачение французского интервенционизма» не получила ожидавшегося международного резонанса и признания справедливости судебного приговора. Этот сюжет стал лишь широко используемым советской стороной пропагандистским ресурсом.

Зарубежная пропаганда, рассчитанная на поддержку левых кругов интеллигенции и рабочего движения и проходившая прежде всего по линии Коминтерна путем организации (с акцентом на Францию) массовых протестов против угрозы интервенции в отношении СССР, самими организаторами оценивалась весьма критически. Выступая на совещании Агитпропа Коминтерна 21 января 1931 г. его руководитель Серафима Гопнер не удержалась от резких заявлений: «Отсутствие демонстраций во Франции является позором [...] если подвести итог, то надо сказать, что в отношении массовых 
акций мы имеем колоссальную диспропорцию между нашими усилиями и результатами» ${ }^{8}$.

В СССР на протяжении всего процесса пропаганда формировала установку «Смерть вредителям!», которая из-за своей очевидности стала достоянием массового сознания, своего рода нормативной реакцией на то, чем должен завершиться судебный процесс. Поэтому постановление Президиума ЦИК СССР, последовавшее после вынесенного Верховным Судом приговора о замене смертной казни в отношении пяти осужденных (Рамзина и др.) 10-летним сроком заключения, вызвало бурю негодования, недоумения, растерянности буквально во всех слоях населения, следивших за ходом судебных заседаний. В секретариат ЦИК СССР и лично М.И. Калинину было направлено значительное число протестных писем и телеграмм, в которых зафиксирована позиция рабочих, крестьян, красноармейцев, учащихся, 25-тысячников, учителей, инженеров и др. Эти документы примечательны не только требованиями или просьбами вернуться к расстрельному приговору для «вредителей», но и попытками найти объяснения смягчению приговора - от разочарований в правильности репрессивной политики до негативных выводов о проникновении «вредительства» на самый «верх». Своим актом о смягчении приговора Рамзину и К을 власть вызвала крайне деструктивную для себя реакцию тех слоев, которые считались ее надежной опорой. Это вынужден был признать Вышинский, выступая перед работниками Наркомпроса 9 декабря: «Конечно, было бы очень хорошо никогда Правительству, руководящему государством, не встречаться в каком-нибудь конфликте с массой своего населения, со своим классом» [Судебный процесс... Кн.2, 2017. С. 735].

Власть не вполне прогнозировала и последствия арестов в 1929-1930 гг. почти двух тысяч представителей научнотехнической интеллигенции, обвиненных в принадлежности к «Промпартии», что привело к дезорганизации в работе крупных отраслевых производственных и исследовательских учреждений. Впрочем, во второй половине 1930-го - начале 1931 г. для осужденных во внесудебном порядке Коллегией ОГПУ

\footnotetext{
${ }^{8}$ Российский государственный архив социально-политической истории. Ф. 495. Оп. 30. Д. 706. Л. $15,17$.
} 
к различным срокам заключения специалистов была найдена форма принудительного использования их интеллектуального потенциала - создана под эгидой ЭКУ ОГПУ сеть Особых технических бюро (ОТБ), впоследствии окрещенных «шарашками», числом более 20. В одном из них (ОТБ-11) под руководством Рамзина был реализован проект прямоточного котла, благодаря чему он и еще несколько человек в 1936 г. оказались амнистированы. Через «шарашки» в первой половине 1930-х гг. прошли такие выдающиеся ученые, как конструкторы Б.С. Стечкин, Н. А. Доллежаль, теплотехник М.В. Кирпичев и др. (восемь академиков и членов-корреспондентов), получившие персональную реабилитацию по данному «делу» только в послесталинский период. Немало крупных специалистов, несмотря на отбытие сроков заключения работами в ОТБ, оказались повторно репрессированными и погибли в годы «Большого Террора».

Выдающийся российский адвокат Николай Константинович Муравьев, известный до революции защитой подсудимых на громких политических процессах, один из защитников лидеров эсеровской партии на суде в 1922 г. (что послужило вскоре причиной его ареста и ссылки на несколько лет), во время своего допроса в ГПУ 25 августа 1922 г. дал четкую оценку такого рода процессам: «Я думаю, что с политическими задачами нельзя ни создавать процессов, ни расширять их рамки. Я думаю, что процесс следовало бы вести в узких рамках нарушения Уголовного кодекса. Единственным основанием для процесса должны были бы быть [...] не требования демонстрантов, а действующий Закон. Суд должен быть судом и только судом...» [Высылка..., 2005. С. 294].

\section{Литература}

Высылка вместо расстрела. Депортация интеллигенции в документах ВЧК ОГПУ. 1921-1923. М.: Русский путь, 2005. 544 с.

Письма И. В. Сталина В.М. Молотову. 1925-1936 гг. Сб. док. М.: Россия молодая, 1995. 303 с.

Следствие. Учебное пособие по чекистской работе. М., 1941. 255 с.

Судебный процесс «Промпартии» 1930 г.: подготовка, проведение, итоги: в 2 кн. Кн. 1. М.: Политическая энциклопедия, 2016. 855 с. (Архивы Кремля).

Судебный процесс «Промпартии» 1930 г.: подготовка, проведение, итоги: в 2 кн. Кн. 2. М.: Политическая энциклопедия, 2017. 1055 с. (Архивы Кремля). 
Для цитирования: Красильников С.А. Инсценирующая диктатура: судебный процесс «Промпартии» 1930 г.// ЭКО. 2019. № 7. C. 173-192. DOI: 10.30680/ ECO0131-7652-2019-7-173-192

\section{Summary}

Krasilnikov, S.A., Doctor of Historical Sciences, Leading Researcher of the Institute of History, SB RAS; Novosibirsk State University, Novosibirsk

\section{Staging Dictatorship: the «Industrial Party» Trial of 1930}

Abstract. In 1930, Stalin's leadership was searching for ways to overcome escalating crises in the country and abroad (growth of social tension and protest attitudes in society towards the government, interstate trade and economic conflicts, etc).In this context, it became inevitable to address the previously tested social mobilization technologies in the fight against "internal and external enemies" by using the justice. The mythical Industrial Party Trial was the first fully staged political process in the USSR. In the course of its conduction, for the first time such a massive combination of modern propaganda tools (filming, radio broadcasts from the courtroom, daily coverage of hearings in newspapers is almost identical to the transcript) were used by the authorities for influencing the public consciousness not only of the population of the Soviet Union, but also the left and labor movements of foreign countries. The process of the "Industrial Party" had its downside, concealing the goals and intentions of its organizers, which can be reconstructed by analysis of the official documents and materials of the Party-State and Chekist structures. The article analyzes the problem of opportunities and limitations of the use by Stalin's leadership of this judicial process as a means of controlling the behavior of the masses in the early Soviet society.

Keywords: open court proceedings; mythological «Industrial Party»; Stalin; Ramzin; France; «interventionism»

\section{References}

Expulsion instead of Execution. Deportation of Intellectuals in the Documents of the Cheka-OGPU. 1921-1923. (2005). Moscow, Russian way. 544 p. (In Russ.).

Letters of I. V. Stalin to V.M. Molotov. 1925-1936. (1995). Collection of Documents. Moscow, Russia is Young. 303 p. (In Russ.).

The Investigation. A Manual on the Work of Chekist. (1941). Moscow, 255 p. (In Russ.).

The Trial of the "Industrial Party" of 1930: Preparation, Conduct, Results: in 2 books. Book 1. (2016). Moscow, Political Encyclopedia. 855 p. (Kremlin archives). (In Russ.).

The Trial of the "Industrial Party" of 1930: Preparation, Conduct, results: in 2 books. Book 2. (2017). Moscow, Political Encyclopedia Publ. 1055 p. (Kremlin archives). (In Russ.).

For citation: Krasilnikov, S. A. (2019). Staging Dictatorship: the «Industrial Party» Trial of 1930. ECO. No. 7. Pp. 173-192. (In Russ.). DOI: 10.30680/ECO01317652-2019-7-173-192 